\title{
Interactive comment on "Anthropogenic and natural drivers of a strong winter urban heat island in a typical Arctic city" by Mikhail Varentsov et al.
}

\section{Anonymous Referee \#2}

Received and published: 1 October 2018

The paper presents results of an unique observation dataset, obtained in the Russian polar area, specifically in the Apatity city and its surroundings. Observed data together with satellite measurements and high-resolution model results give an interesting view in the urban heat island in polar region. I have following comments to the text:

Specific comments:

1) Page 2, line 15: The winter UHI in mid-latitude cities is not so environmental problem, but it can be significant and also dependent on the anthropogenic heat release. E.g., Bohnenstengel et al. (2012) conclude impact of $\mathrm{AH}$ to $1.5 \mathrm{~K}$ in December in London. Also model studies (Trusilova et al., 2016; Huszar et al., 2014) found the winter UHI in central European cities. 
2) P. 5, I. 23: What does it mean TERRA_URB switched off - removing of urban fraction from model grid-boxes (annihilation approach, e.g. Baklanov, 2016) or only not using of TERRA_URB parametrization? The second option admits that still some physical properties of the surface are altered for urban grid cells (by default in the model).

3) P. 7, I. 10: The conclusion about AHF is too fast. Despite a very low solar radiation, the UHI is not created only by AHF. E.g., a reduced long-wave radiation in the urban environment (due to reduced sky-view factor) can also contribute to the UHI formation in calm anticyclonic situations. Similarly in discussion (p. 8, I. 10-11), the driver could be mentioned.

4) P. 8, I. 5: It is inaccurately to attribute the temperature difference between U1 and $\mathrm{R} 1$ as the "UHI intensity" and moreover, compare it with values for listed megacities. The U1-R1 difference is created not only by anthropogenic factors. Only about $50 \%$ $(1 \mathrm{~K})$ is caused by $\mathrm{UHI}$ effects, as correctly written in the conclusion.

5) P. 9, I. 13: What is the base of the selection of six cold periods? The observed U1-R1 differences are sometimes higher and more persistent in other periods (Fig. 7), e.g. after 9th or 19th January. Need to clarify.

6) P. 11, I. 5: There is no clear evidence for the conclusion "The AHF during extreme cold days may warm the city center by up to $6 \mathrm{~K}$ ". The $50 \%$ contribution of all anthropogenic impact is in the time average (as you wrote in p. 9., I. 28).

7) Abstract: The values of $1.9 \mathrm{~K}$ and $11 \mathrm{~K}$ are misleading, because there is no information about different altitudes, which has a significant impact (of the same magnitude as the anthropogenic impact).

8) Abstract: The sentence "... direct anthropogenic heating contributes at least $50 \%$ to the observed $\mathrm{UHI}$ intensity, and the rest is created by natural microclimatic variability..." is wrong, because the UHI intensity can not be created (in principle) by "natural micro-climatic variability.... The true sentence is "At least $50 \%$ of this warm anomaly

Printer-friendly version

Discussion paper
Interactive

comment 
is caused by the UHI effect, driven mostly by direct anthropogenic heating.", as written in conclusion.

Technical corrections:

1) P. 3, I. 15: The sentence and all paragraph (comparison with other studies) belongs rather to discussion. In this part of introduction, aims of study should be specified.

Interactive

comment

2) Figure 4: The shaded area is clearly larger than 1. But the integral from the probability density function over all temperatures should be equal to one. Please, norm the probability values in both figures.

3) Figure 7: There should be some warning (or another "name" besides "case") that cases in Fig. 7 are not the same as in Fig. 3, Fig. 5 and Fig. S4.

Baklanov, A., Molina, L. T., and Gauss, M.: Megacities, air quality and climate, Atmospheric Environment, 126, 235 - 249.

Bohnenstengel, S. I., Hamilton, I. , Davies, M. and Belcher, S. E. (2014), Impact of anthropogenic heat emissions on London's temperatures. Q.J.R. Meteorol. Soc., 140: 687-698. doi:10.1002/qj.2144

Trusilova, K., Schubert, S., Wouters, H., Früh, B., Grossman-Clarke, S., Demuzere, M., and Becker, P.: The urban land use in the COSMO-CLM model: a comparison of three parameterizations for Berlin, Meteorologische Zeitschrift, 25, 231-244, doi:10.1127/metz/2015/0587, URL http://dx.doi. org/10.1127/metz/2015/0587, 2016.

Huszar, P., Halenka, T., Belda, M., Zak, M., Sindelarova, K., and Miksovsky, J.: Regional climate model assessment of the urban land-surface forcing over central Europe, Atmospheric Chemistry and Physics, 14, 12 393-12 413, doi: 10.5194/acp-14-123932014, URL https://www.atmos-chem-phys.net/14/12393/2014/, 2014.

Interactive comment on Atmos. Chem. Phys. Discuss., https://doi.org/10.5194/acp-2018-569, 2018. 